\title{
INTEGRAL ASSESSMENT OF THE EFFECTIVENESS \\ OF THE FUNCTIONING OF CAR SERVICE STATIONS
}

\section{ІНТЕГРАЛЬНА ОЦІНКА ЕФЕКТИВНОСТІ ФУНКЦІОНУВАННЯ СТАНЦІЙ ТЕХНІЧНОГО ОБСЛУГОВУВАННЯ АВТОМОБІЛІВ}

\author{
Volodymyr O. Khavruk \\ khavruk@gmail.com \\ ORCID: 0000-0002-4686-4109
}

\author{
В. О. Хаврук \\ асистент
}

National Transport University, Kyiv

Наиіональний транспортний університет, м. Київ

\begin{abstract}
The effectiveness of the functioning of a car service station is characterized by two groups of indicators: quantitative and qualitative. Among the quantitative indicators, the following were identified: reliability of operation, throughput, average waiting time, degree of profitability; among the quantitative ones - the speed of work, the convenience of the operating mode, the qualifications of the personnel, the guarantee and the cost of the work, the range of services, the politeness of the staff, the availability of spare parts, and technological equipment. The weight was determined and standardized for these indicators for three options for the operation of the service station: 1) the current situation (selected in terms of the possibility of comparing changes in the performance of car service centers) 2) the situation corresponding to the maximum efficiency criterion for each of the sites; 3 ) the situation was suggested by the management of a car service, which corresponds to the final description based on the results of modeling production sites.

For the KyivSkhid car service station, it was found that when the number of calls to the car service is 30-50 per day, the minimum values for waiting for cars to be repaired will be provided at a production capacity of 64-95 peoplehours. Accordingly, appropriate decisions can be made within these limits by the number of posts for repair. For this car service, in connection with the small area of the production building, it was decided to use 6 posts of the repair zone - option No. 3, thanks to which the production capacity of 72 people-hours is provided. Despite the fact that all posts in the repair zone of a car service are equipped with lifts, and therefore such posts are universal, in which, in the absence of separate specialized work, for example, diagnosing electronic systems, other repair work can be performed, underloading or downtime can be minimized.
\end{abstract}

Purpose. Based on a combination of quantitative and qualitative indicators of the functioning of a car service station, carry out an integrated assessment of the effectiveness of a particular car service station.

Method. An analysis of the production activities of the car service station made it possible to form two groups of indicators of the effectiveness of the repair zone. Using the method of expert estimates, the weight of each of the indicators is determined. An integrated assessment of the effectiveness of the repair zone of a car service center is presented in a formalized form.

Results. Using 6 posts of the repair zone compared to 4 posts allows you to increase the integrated efficiency of a car service by $21 \%$ while reducing the waiting line for service during peak periods of service stations and as a result, the throughput is increased by $16-18 \%$.

Scientific novelty. It is proposed to carry out an integrated assessment of the effectiveness of the maintenance station using normalized quantitative and qualitative indicators.

Practical importance. Using the example of a specific car service station with the number of service calls 30-50 per day, it is proposed to use 6 production posts.

Key words: production and technical base; expert; efficiency; assessment; company; indicator; car service station.

Анотація. Ефективність функціонування станції технічного обслуговування автомобілів характеризується двома групами показників: кількісними і якісними. До кількісних показників належать: надійність функціонування, пропускна здатність, середній час очікування, міра прибутковості; до якісних - швидкість виконання робіт, зручність режиму роботи, кваліфікація персоналу, гарантія і вартість робіт, спектр послуг, ввічливість персоналу, наявність запчастин, технологічна оснащеність. Визначена вага та здійснено нормування даних показників для трьох варіантів функціонування станції технічного обслуговування: 1) існуюча ситуація (вибрана 3 точки зору можливості порівняння зміни ефективності діяльності автосервісу); 2) ситуація, що відповідає максимуму критерію ефективності по кожній з дільниць; 3) запропонована керівництвом автосервісу ситуація, що відповідає завершальному опису за результатами моделювання виробничих дільниць. 
Для СТО «КиївСхід» встановлено, що за кількості звернень на автосервіс 30-50 на добу мінімальні значення часу очікування автомобілів на ремонт будуть забезпечуватися за умови виробничої потужності 64-95 люд./ год. Відповідно, в цих межах можна приймати відповідні рішення щодо кількості постів для ремонту. Для вказаного автосервісу, у зв’язку з невеликою площею виробничої будівлі, було прийнято рішення використовувати 6 постів ремонтної зони - варіант № 3, завдяки якому забезпечується виробнича потужність 72 люд./год. Зважаючи на те, що всі пости ремонтної зони автосервісу оснащені підйомниками, а тому такі пости є універсальними, на яких у разі відсутності окремих спеціалізованих робіт, наприклад діагностування електронних систем, можуть виконуватись інші ремонтні роботи, а недозавантаженість або простій можливо звести до мінімуму.

Мета статті - на основі сукупності кількісних і якісних показників функціонування станції технічного обслуговування автомобілів здійснити інтегральну оцінку ефективності функціонування конкретної станції технічного обслуговування автомобілів.

Методика. Аналіз виробничої діяльності станції технічного обслуговування автомобілів дав змогу сформувати дві групи показників ефективності функціонування ремонтної зони. За допомогою методу експертних оцінок визначено вагу кожного із показників. Інтегральна оцінка ефективності функціонування ремонтної зони автосервісу представлена у формалізованому вигляді.

Результати. Використання 6 постів ремонтної зони порівняно з 4-ма постами дозволяє підвищити комплексну ефективність автосервісу на $21 \%$ за скорочення черги на очікування обслуговування в період пікових навантажень на СТО і як результат, збільшується пропускна спроможність на 16-18\%.

Наукова новизна. Запропоновано здійснювати інтегральну оцінку ефективності функціонування станції технічного обслуговування з використанням пронормованих кількісних і якісних показників.

Практична значимість. На прикладі конкретної станції технічного обслуговування автомобілів за кількості звернень у сервіс - 30-50 на добу запропоновано використовувати 6 виробничих постів.

Ключові слова: виробничо-технічна база; експерт; ефективність; оцінка; підприємство; показник; станція технічного обслуговування автомобілів.

\section{ПОСТАНОВКА ПРОБЛЕМИ}

Сфера автосервісу характеризується високою конкуренцією у зв'язку з наявністю великої кількості станцій технічного обслуговування (СТО). Автовласники віддають перевагу тим СТО, які надають якісні автосервісні послуги у короткі строки за прийнятну ціну. Щоб забезпечувати вимоги автовласників, для будь-якої СТО постійно існує проблема покращення свого конкурентного становища, тобто підвищення ефективності своєї виробничої діяльності.

\section{АНАЛІЗ ОСТАННІХ ДОСЛІДЖЕНЬ І ПУБЛІКАЦІЙ}

Оцінка ефективності функціонування СТО здійснювалась науковцями у численних публікаціях, на особливу увагу заслуговують дослідження таких авторів, як Р.В. Абаімов [1], С.В. Афанасьєв [2], С.В. Рябченко [3], А.М. Соколов [4], І.В. Фірсов [5], А.Є. Чернишов [6]. Наукові роботи авторів характеризуються досить обмеженою характеристикою факторів, якими визначається ефективність СТО, при цьому основним показником виступає пропускна здатність СТО.

\section{ВІДОКРЕМЛЕННЯ НЕ ВИРІШЕНИХ} РАНІШЕ ЧАСТИН ЗАГАЛЬНОЇ ПРОБЛЕМИ

Необхідно зауважити, що ефективність СТО у наданні автосервісних послуг $є$ неоднозначною характеристикою, яка визначається багатьма показниками, що мають якісну і кількісну оцінку. Спеціальні дослідження оцінки ефективності СТО в сучасних умовах 3 комплексним урахуванням як кількісних, так і якісних показників, а також динаміки їх зміни в реальному масштабі часу не здійснювалися. Це i зумовлює необхідність проведення таких досліджень.

Мета дослідження - розглянути кількісні i якісні показники функціонування СТО та здійснити інтегральну оцінку ефективності функціонування конкретної станції технічного обслуговування автомобілів.

\section{МЕТОДИ, ОБ'СКТ ТА ПРЕДМЕТ ДОСЛІДЖЕННЯ}

Основними методами дослідження ефективності функціонування автосервісу $\epsilon$ емпіричний, який включає спостереження, вимірювання показників, моделювання та загальнологічний - аналіз структури зони поточного ремонту СТО.

Об'єктом дослідження є станція технічного обслуговування автомобілів, предмет дослідження кількісні і якісні показники ефективності функціонування автосервісу.

\section{ОСНОВНИЙ МАТЕРІАЛ}

Показники функціонування станції технічного обслуговування (СТО), а також методи прогнозування, дозволяють цілеспрямовано підійти до формування відповідного методичного підходу, що забезпечує безпосереднє здійснення вибору найбільш ефективного варіанту діяльності виробництва. Такими показниками $\epsilon[6$, с. 95]:

1) наявність в СТО достатньої пропускної спроможності - Ард - для задоволення існуючого і 
перспективного попиту на його послуги. Врахування цього показника потрібно з тієї точки зору, що його перевищення над деяким оптимальним значенням різко збільшує простої виробничого персоналу, a, отже, витрати СТО. Навпаки, недолік пропускної спроможності призводить до збільшення черг на обслуговування, що часто призводять до втрати потенційних та існуючих клієнтів i, відповідно, прибутків СТО, але в той же час знижує витрати підприємства;

2) наявність досить широкого набору послуг, оскільки цей показник характеризує перспективні можливості СТО з точки зору його статусу на ринку. Збільшення кількості послуг, що надаються, зазвичай неминуче призводить до зростання витрат СТО, але при цьому також збільшується привабливість підприємства для клієнтів. Зменшення кількості послуг навпаки призводить до вужчої спеціалізації підприємства, до підвищення кваліфікації персоналу і як наслідок - до підвищення ефективності послуг, що надаються;

3) середній час очікування обслуговування $-\bar{t}_{\text {оч. }}$ , як один $з$ показників ефективності обслуговування СТО, вказує на такий важливий фактор, як втрати часу клієнтів підприємства, ритмічність роботи його виробничих підрозділів, продуктивність підприємства, а також, побічно, на наявність достатньої виробничотехнічної бази (ВТБ). Збільшення цього показника призводить до втрат клієнтів підприємства. Причому необхідно враховувати, що ці втрати негативно позначаються на майбутніх періодах, оскільки у разі відмови в обслуговуванні клієнт наступного разу може скористатися послугами конкурента. Зменшення середнього часу обслуговування призводить до збільшення витрат, що для СТО є негативним фактором в забезпеченні його конкурентоспроможності;

4) міра прибутковості (рентабельність) МПр функціонування підприємства, 3 урахуванням надійності його роботи - Р. Врахування цих показників необхідно, оскільки вони характеризують економічність використання усіх ресурсів СТО, його продуктивність і, отже, стійкість в умовах ринку;

5) крім кількісних показників, під час проведення комплексної оцінки ефективності необхідно враховувати якісні показники, що характеризують [6, с. 96]: охопленість послуг; відповідальність СТО, гарантія виконаних послуг; компетентність персоналу; легкість встановлення контактів з сервісною фірмою, зручний для споживача час надання сервісних послуг; відсутність ризику і недовіри з боку споживача (наприклад, забезпечення збереження належного зовнішнього вигляду і чистоти салону автомобіля); ввічливість персоналу.

Проведення комплексного аналізу вищевідзначеної сукупності показників, що мають різний фізичний зміст і розмірність, здійснюється 3 використанням наявних методів багатокритерійного аналізу таким чином.

На першому етапі проводиться відбір достатньої кількості експертів (включаючи кваліфікований персонал СТО).

На другому етапі проводиться безпосереднє формування сукупності показників ефективності функціонування СТО, причому на цьому етапі до запропонованих показників експерти можуть додати ряд своїх, що характеризують ефективність діяльності стосовно конкретного СТО.

На третьому етапі здійснюється групування сформованої сукупності показників ефективності $\tau \mathrm{s}$, $S=(\overline{1, n})$ за такими групами:

- кількісні показники (тобто ті, які мають розмірність і можуть бути визначені за допомогою використання різних залежностей), збільшення яких призводить до зростання ефективності функціонування досліджуваного підприємства $\tau_{S}^{(+)}$, $S=(\overline{1, n})$;

- кількісні показники, збільшення яких навпаки призводить до зниження ефективності $\tau_{S}^{(-)}$, $s=(\overline{k+1, b})$;

- якісні показники, отримання яких можливе тільки 3 використанням експертизи, $\tau_{S}^{(\text {() }}$, $s=(\overline{b+1, n})$.

Необхідно зазначити, що для подальшого використання в методиці інтегральної оцінки ефективності функціонування СТО для кожного 3 показників необхідне отримання оцінок, що характеризують ïx важливість, наприклад показник питомої ваги, що $є$ завданням четвертого етапу. На цьому етапі здійснюється ранжування показників 3 використанням стандартної методики (ранжування проводиться окремо для кількісних, окремо для яқісних показників), виявлення загальної суми рангів $\sum a_{S i}$ по кожній з груп (де: $\mathrm{i}$ - індекс експерта, n $-i=$ загальна чисельність експертів, $\mathrm{aSi}$ - ранг $\mathrm{S}$-го показника, присвоєний i-м експертом), оцінка узгодженості W, оцінка невипадковості $\left(\chi_{\text {виб. }}^{2} \equiv \chi_{\text {таб. }}^{2}\right)$. Результатом проведеного ранжування $є$ отримання вагової оцінки даних показників ефективності («важливості», що $є$ числовим значенням), за допомогою залежності [6, с. 98]:

$$
\lambda_{S}=\frac{2\left(n-I_{S}+1\right)}{n(n+1)},
$$

де: $n$ - загальне число даних показників; $I_{S}-$ місце, займане $S$-м показником під час ранжування по сумі рангів.

Для показників, які можна оцінити тільки якісним чином, на цьому етапі здійснюється бальна оцінка (кожним експертом з їх загальної сукупності надається конкретне значення балу від 1 до 10). При цьому враховуються наступні допущення: значення 
бальної оцінки показників випадкові; на думку експертів, на проведення бальної оцінки впливає велика кількість факторів, але можливі значення оцінок можуть лежати в межах деякого інтервалу. Ці допущення зумовлюють нормальність або рівномірність розподілів оціночних показників.

Перед проведенням комплексної оцінки ефективності функціонування даної СТО необхідно зробити нормування порівнюваних показників, оскільки більшість 3 них мають різний фізичний зміст i розмірність.

Для показників, збільшення яких призводить до зростання ефективності функціонування досліджуваного підприємства, нормування здійснюється таким чином [6, с. 99]:

$$
Y_{S}^{(+)}=\frac{\tau_{S}^{(+)}-\tau_{S(x)}^{(+)}}{\tau_{S}^{(+)}}
$$

де: $Y_{S}^{(+)}-$пронормоване значення показників даної групи; $\tau_{S}^{(+)}-$поточне значення показників групи; $\tau_{S(x)}^{(+)}-$найгірше значення показника даної групи із даної сукупності $s=(\overline{1, k})$.

Для показників, збільшення яких призводить до зниження ефективності функціонування досліджуваної СТО, нормування виконується таким чином:

$$
Y_{S}^{(-)}=\frac{\tau_{S(x)}^{(-)}-\tau_{S}^{(-)}}{\tau_{S(x)}^{(-)}}
$$

де: $Y_{S}^{(-)}-$пронормоване значення показників даної групи; $\tau_{S}^{(-)}-$поточне значення показників цієї групи; $\tau_{S(x)}^{(-)}-$краще значення показника даної групи із даної сукупності $s=(\overline{k+1, b})$.

Під час проведення цієї оцінки необхідно враховувати, що кращим показникам типу $\tau_{S}^{(+)}$мають відповідати найбільші нормовані значення, і навпаки - кращим показникам типу $\tau_{S}^{(-)}$мають відповідати найменші пронормовані значення.

Нормування якісних показників, що мають бальну оцінку, здійснюється наступним чином [6, с. 100]:

$$
Y_{S}^{(\mathrm{Б})}=\frac{\tau_{S}^{(\mathrm{Б})}-\tau_{S(x)}^{(\mathrm{Б})}}{\tau_{S}^{(\mathrm{Б})}},
$$

де: $Y_{S}^{(\text {Б) }}$ - пронормоване значення показників даної групи; $\tau_{S}^{(\text {Б) }}$ - поточне значення показників групи; $\tau_{S(x)}^{(\text {() }}$ - гірше значення показника цієї групи із заданої сукупності.

Представлений механізм нормування має істотний недолік - гіршому значенню показника завжди відповідатиме нульове пронормоване значення. Тоді під час порівняння різних варіантів функціонування виробничої бази СТО може скластися наступна ситуація: за наявності гірших показників тільки в одного 3 варіантів, остаточне значення критерію ефективності по ньому дорівнюватиме нулю, що робить неможливим подальше їх адекватне порівняння. Усунення цього недоліку можливе шляхом зміщення пронормованих оцінок, таким чином:

$$
Y_{S}^{\prime}=Y_{S}+\max \left\{Y_{S}\right\},
$$

де $\max \left\{Y_{S}\right\}-$ максимум із прогнозованих значень одного й того ж самого показника за різними варіантами функціонування ВТБ СТО.

Остаточна інтегральна оцінка ефективності функціонування підрозділів СТО здійснюється на основі $[6$, с. 101]:

$$
\begin{aligned}
& E=\omega_{1} \times\left(\sum_{s=1}^{k} Y_{S}^{(+)} \cdot \lambda_{S}^{(+)}+\sum_{S=k+1}^{b} Y_{S}^{(-)} \cdot \lambda_{S}^{(-)}\right)+ \\
& +\omega_{1} \times \sum_{S=b+1}^{n} Y_{S}^{(\mathrm{Б})} \cdot \lambda_{S}^{(\text {Б })} \rightarrow \max
\end{aligned}
$$

де $\omega_{1}, \omega_{2}-$ відповідно питомі ваги для кількісної і якісної оцінок. Якщо їх значення невідомі (або ï визначення неможливе), виходячи 3 умови «невизначеності» міри впливу вагів $\omega_{1}$ i $\omega_{2}$ на кінцевий результат, приймається принцип їх рівномірного впливу (жодному не віддається перевага) і призначаються рівні ваги $\omega_{1}=\omega_{2}=0,5$. Оскільки визначення остаточного критерію ефективності СТО здійснюється на основі формули (6), що має адитивний характер, зміщення значень пронормованих показників не впливає істотно на значення отримуваної оцінки.

Наведена методика дозволяє оцінити інтегральну ефективність функціонування СТО на основі врахування великої кількості показників, а також порівнювати між собою різні варіанти налаштування виробничих потужностей як окремих виробничих дільниць, так і підприємства в цілому. При цьому найкращому варіанту відповідає максимум $E$.

Моделювання кількісних показників, що характеризують функціонування виробничих підрозділів СТО «КиївСхід», створює умови для остаточної інтегральної оцінки його діяльності. Виходячи 3 умови забезпечення довгострокового існування підприємства, під час проведення цієї оцінки необхідно враховувати не лише економічні показники (доходи, витрати, прибуток), але і показники, що важливі для його клієнтів. Методика дозволяє отримувати оцінки ефективності того або іншого варіанту функціонування виробництва, з урахуванням всієї сукупності наведених вище показників.

Першим етапом здійснення комплексної оцінки є визначення кількісних показників. В якості таких варіантів 
для моделювання кількісних показників ефективності функціонування підприємства в цілому приймалися:

- варіант № 1 - існуюча ситуація (вибрана 3 точки зору можливості порівняння зміни ефективності діяльності СТО);

- варіант № 2 - ситуація, що відповідає максимуму критерію ефективності Е по кожній з дільниць;

- варіант № 3 - запропонована керівництвом СТО ситуація, що відповідає завершальному опису за результатами моделювання виробничих дільниць. Для дільниць діагностування електронних систем і електротехнічних робіт приймається існуюча ситуація (по одному виробничому посту), оскільки збільшення виробничої потужності для них недоцільне. Для дільниць ремонту вузлів і агрегатів і загального ремонту приймається варіант, що відповідає максимуму критерію ефективності Е (по 2 виробничі пости).

Результати визначення кількісних показників для СТО в цілому представлені в табл. 1.

Другим етапом інтегральної оцінки ефективності функціонування ПА є врахування якісних показників. Для цього в процесі проведення досліджень щодо вивчення відношення клієнтів до роботи СТО була сформована відповідна їх сукупність. Подальша обробка результатів дозволила оцінити їх важливість (рангова оцінка) i міру задоволення роботою СТО (бальна оцінка) [7, с. 176-182]. Аналогічні дослідження думки клієнтів проводилися за зміни налаштування роботи СТО по варіанту № 3. Загальне поліпшення показників роботи СТО дозволяє стверджувати, що (по ії роботі з клієнтами) оцінка варіанту №3 порівняно з варіантом № 2 не будуть гірші. На користь цього твердження також свідчить той факт, що кількісні показники по цих двох варіантах співставні. Як випливає 3 табл. 2, загальна оцінка результатів діяльності СТО клієнтами також покращилась.

Початкові дані для проведення інтегральної оцінки функціонування СТО «КиївСхід» представлені в табл. 2. Оскільки показники, що враховуються, мають різні фізичний зміст (бали, фізичні величини) і розмірність по кожній з груп показників, для оцінки ефективності функціонування СТО здійснюється їх нормування - формули (1-4), результати якого наведені в табл. 3.

Таблиця 1. Результати оцінки варіантів функціонування СТО «КиївСхід»

\begin{tabular}{|c|c|c|c|c|c|}
\hline \multirow{2}{*}{ Показник } & \multirow{2}{*}{ Позначення } & \multirow{2}{*}{$\begin{array}{c}\text { Важливість } \\
\text { показника («вага») }\end{array}$} & \multicolumn{3}{|c|}{$\begin{array}{c}\text { Варіанти налаштування } \\
\text { виробництва }\end{array}$} \\
\cline { 4 - 7 } & & - & 48 & 96 & $\mathbf{7 2}$ \\
\hline Виробнича потужність, (люд.год.) & Мділ. & 0,3 & 0,451 & 0,996 & $\mathbf{0 , 9 6 3}$ \\
\hline Надійність функціонування & Рділ. & 0,1 & 27,04 & 55,39 & $\mathbf{3 6 , 3}$ \\
\hline Пропускна спроможність, авт./добу & $A$ рд & 0,2 & 270,63 & 0,489 & $\mathbf{0 , 4 9 4}$ \\
\hline Середній час очікування, годин & $\bar{t}_{\text {оч. }}$ & 0,4 & 1,3 & 1,46 & $\mathbf{1 , 5 7}$ \\
\hline Міра прибутковості & МПр. & - & 3 & 8 & 6 \\
\hline Кількість постів & $k$ & & & & \\
\hline
\end{tabular}

Таблиця 2. Початкові дані для проведення інтегральної оцінки функціонування СТО «КиївСхід»

\begin{tabular}{|c|c|c|c|c|c|}
\hline \multirow{2}{*}{ Показник } & \multirow{2}{*}{ Позначення } & \multirow{2}{*}{$\begin{array}{c}\text { Важливість } \\
\text { показника («вага») }\end{array}$} & \multicolumn{3}{|c|}{ Бали } \\
\hline & & & Bap. 1 & Bap. 2 & Bap. 3 \\
\hline \multicolumn{6}{|c|}{ Якісні показники } \\
\hline Швидкість виконання робіт & $\mathrm{X} 1$ & 0,106 & 4,79 & 5,00 & 5,00 \\
\hline Зручність режиму роботи & $\mathrm{X} 2$ & 0,115 & 4,96 & 5,00 & 5,00 \\
\hline Кваліфікація персоналу & X3 & 0,113 & 4,88 & 5,00 & 5,00 \\
\hline Гарантія на роботи & $\mathrm{X} 4$ & 0,113 & 4,88 & 4,88 & 4,88 \\
\hline Вартість робіт & $\mathrm{X} 5$ & 0,111 & 4,80 & 4,80 & 4,80 \\
\hline Спектр послуг, що надаються & $\mathrm{X} 6$ & 0,113 & 4,88 & 4,88 & 4,88 \\
\hline Ввічливість персоналу & $\mathrm{X} 7$ & 0,107 & 4,83 & 5,00 & 5,00 \\
\hline Наявність запчастин & $\mathrm{X} 8$ & 0,110 & 4,76 & 4,76 & 4,76 \\
\hline Технологічна оснащеність & X9 & 0,112 & 4,84 & 4,84 & 4,84 \\
\hline \multicolumn{6}{|c|}{ Кількісні показники } \\
\hline Показник & Позначення & \begin{tabular}{|c|} 
Важливість \\
показника («вага»)
\end{tabular} & \multicolumn{3}{|c|}{ Значення параметрів } \\
\hline Надійність функціонування & Рділ. & 0,3 & 0,451 & 0,996 & 0,963 \\
\hline Пропускна здатність, авт./добу & Aрд & 0,1 & 27,04 & 55,39 & 36,3 \\
\hline Середній час очікування, год. & $\bar{t}_{o u}$ & 0,2 & 270,63 & 0,489 & 0,494 \\
\hline Міра прибутковості & MПр. & 0,4 & 1,30 & 1,46 & 1,57 \\
\hline
\end{tabular}


Таблиця 3. Нормування показників оцінки функціонування СТО «КиївСхід»

\begin{tabular}{|c|c|c|c|c|c|}
\hline \multirow{2}{*}{ Показник } & \multirow{2}{*}{ Позначення } & \multirow{2}{*}{$\begin{array}{c}\text { Важливість } \\
\text { показника («вага») }\end{array}$} & \multicolumn{3}{|c|}{ Нормовані величини } \\
\hline & & & Bap. 1 & Bap. 2 & Bap. 3 \\
\hline \multicolumn{6}{|c|}{ Якісні показники } \\
\hline Швидкість виконання робіт & $\mathrm{X} 1$ & 0,106 & 0,068 & 0,136 & 0,136 \\
\hline Зручність режиму роботи & $\mathbf{X} 2$ & 0,115 & 0,038 & 0,076 & 0,076 \\
\hline Кваліфікація персоналу & $\mathbf{X 3}$ & 0,113 & 0,072 & 0,144 & 0,144 \\
\hline Гарантія на роботи & $\mathrm{X} 4$ & 0,113 & 0 & 0 & 0 \\
\hline Вартість робіт & $\mathbf{X 5}$ & 0,111 & 0 & 0 & 0 \\
\hline Спектр послуг, що надаються & X6 & 0,113 & 0 & 0 & 0 \\
\hline Ввічливість персоналу & $\mathbf{X} 7$ & $\mathbf{0 , 1 0 7}$ & 0 & 0 & 0 \\
\hline Наявність запчастин & X8 & 0,110 & 0,072 & 0,144 & 0,144 \\
\hline Технологічна оснащеність & $\mathbf{X 9}$ & 0,112 & 0,070 & 0,140 & 0,140 \\
\hline Критерій & $E_{1}$ & - & 0,0355 & 0,0709 & 0,0709 \\
\hline \multicolumn{6}{|c|}{ Кількісні показники } \\
\hline Показник & Позначення & $\begin{array}{c}\text { Важливість } \\
\text { показника («вага») }\end{array}$ & \multicolumn{3}{|c|}{ Нормовані величини } \\
\hline Надійність & Рділ. & $\mathbf{0 , 3}$ & 0,5472 & 1,0944 & 1,0789 \\
\hline Пропускна здатність, авт./добу & $A \mathrm{pд}$ & $\mathbf{0 , 1}$ & 0,5118 & 1,0237 & 0,7669 \\
\hline Середній час очікування, год. & $\bar{t}_{\text {ou. }}$ & 0,2 & 0,9982 & 1,9964 & 1,9964 \\
\hline Міра прибутковості & MПр. & 0,4 & 0,1720 & 0,3439 & 0,2816 \\
\hline Критерій & $E_{2}$ & - & 0,4838 & 0,9675 & 0,9122 \\
\hline Ефективність функціонування & $E$ & - & 0,2596 & 0,5192 & 0,4916 \\
\hline
\end{tabular}

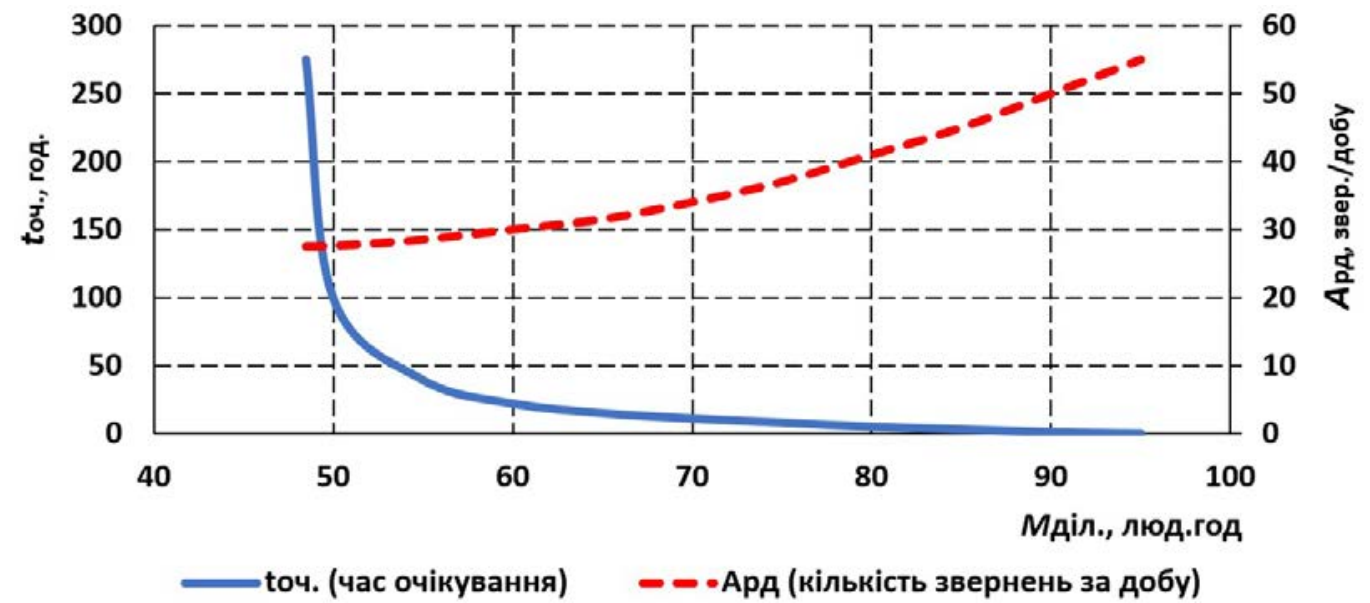

Рис. 1. Результати визначення ефективності функціонування СТО «КиївСхід»

Завершальним етапом $є$ визначення критерію ефективності $E_{i}$ по кожній з груп показників з подальшим визначенням інтегральної ефективності $E$ - формула (6). Причому оскільки значення $\omega_{1}$ і $\omega_{2}$ невідомі, виходячи з принципу невизначеності, було прийнято рішення прийняти $\omega_{1}=\omega_{2}=0,5$.

Остаточні результати визначення ефективності функціонування СТО «КиївСхід» зведені в табл. 3, а графічно - на рис. 1 , рис. 2.

На рис. 2 показана зона прийняття оптимального рішення, що є діапазоном виробничої потужності CTO, в межах якого у керівника підприємства $\epsilon$ можливість варіювати налаштування ВТБ без знач- ного, в межах 90\%-ї зміни ефективності діяльності СТО. Для СТО «КиївСхід» керівництвом був прийнятий третій варіант налаштування ВТБ, оскільки в існуючому виробничому корпусі неможливо розмістити 8 виробничих постів. В той же час за своїми показниками цей варіант трохи відрізняється від другого, але при цьому значно менші витрати на додаткове обладнання і заробітну плату виробничого персоналу.

Використання отриманих результатів на практиці дозволяє підвищити комплексну ефективність діяльності СТО на 21\%, при цьому скорочується черга на очікування обслуговування в період пікових 


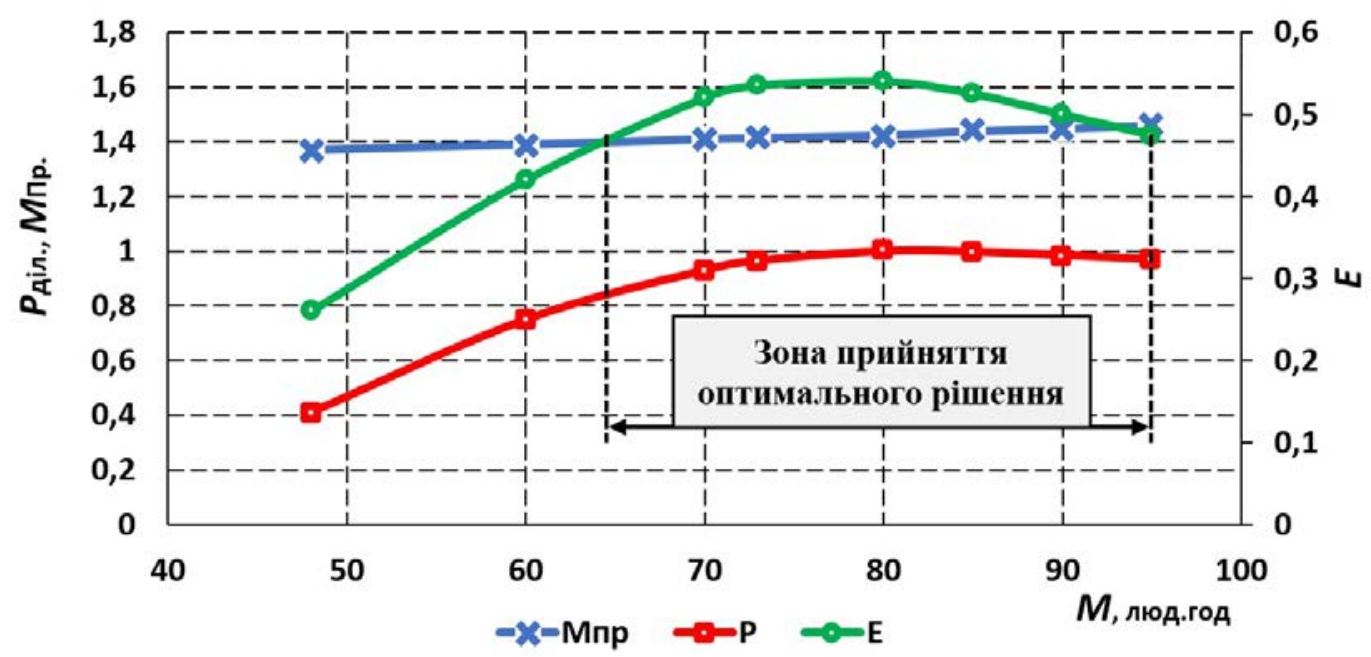

Рис. 2. Зона прийняття оптимального рішення для СТО «КиївСхід»

навантажень на СТО, і збільшується пропускна спроможність на 16-18\%, що дозволить підприємству в майбутньому постійно нарощувати свою частку на ринку надання автосервісних послуг.

\section{ОБГОВОРЕННЯ ОТРИМАНИХ РЕЗУЛЬТАТІВ}

Таким чином, в межах виробничої потужності 64-95 люд./год (рис. 2) для СТО «КиївСхід» досягаються високі значення ефективності функціонування зони поточного ремонту, при цьому необхідно задіяти від 6 до 9 постів. Для забезпечення належного рівня ефективності функціонування ремонтної зони було прийнято рішення використовувати 6 постів.

\section{ВИСНОВКИ}

Отже, сформовано п’ять груп показників, якими характеризується ефективність функціонування
СТО. Аналіз їх здійснюється в чотири етапи, результатом яких $\epsilon$ виділення якісних показників та розмежування кількісних показників на дві групи: 1) що призводять до зниження ефективності СТО; 2) що призводять до підвищення ефективності СТО. На основі інтегральної оцінки ефективності функціонування зони поточного ремонту СТО «КиївСхід» для даного підприємства запропоновано третій варіант налаштування ВТБ з 6-ма постами.

Перспективи подальших досліджень. Для інтегральної оцінки ефективності функціонування станції технічного обслуговування автомобілів у подальшому планується розширити перелік кількісних показників та розробити оптимальну методику їх експертної оцінки.

\section{REFERENCES}

[1] Abaimov, R. V. (2011). Povysheniye effektivnosti proizvodstvennoy deyatelnosti stantsiy tekhnicheskogo obsluzhivaniya legkovykh avtomobiley. Diss. [Improving the efficiency of production activities of passenger car service stations. Diss.]. Orel. $136 \mathrm{p}$.

[2] Afanasev, S. V. (2003). Razrabotka metodiki upavleniya potentsialom proizvodstvennoy moshchnosti predpriyatiya avtoservisa. Diss. [Development of a methodology for managing the potential of the production capacity of a car service enterprise. Diss.]. Moscow. 207 p.

[3] Ryabchenko, S. V. (2005). Ekonomika i upravleniye predpriyatiyami avtoservisa [Economics and management of car service enterprises]. Saint Petersburg: RGPU A. I. Gertsena Pbl. 202 p.

[4] Sokolov, A. M. (2009). Razvitiye sistemy upravleiya konkurentosposobnostyu predpriyatiy avtoservisa. Diss. [Development of a competitiveness management system for car service enterprises. Diss.]. Saint Petersburg. 152 p.

[5] Firsov, I. V. (2015). Povysheniye effektvnosti funktsionirovaniya stantsiy tekhicheskogo obsluzhivaniya na osnove sovershenstvovaniya organizatsionno-proizvodstvennoy struktury. Diss. [Improving the efficiency of the functioning of service stations based on improving the organizational and production structure. Diss.]. Moscow. $153 \mathrm{p}$.

[6] Chernyshov, A. E. (2005). Kompleksnaya otsenka effektivnosti funktsionirovaniya avtoservisnykh predpriyatiy: na primere STO legkovykh avtomobiley. Diss. [Comprehensive assessment of the effectiveness of the operation of car service enterprises: the example of service stations of cars. Diss]. Moscow. 217 p.

[7] Medykovskyi, M. O., Shunevych, O. B. (2011). Doslidzhennia efektyvnosti metodiv vyznachennia vagovykh koefitsiientiv vazhlyvosti [Investigation of the effectiveness of methods of determining weights of importance]. Visnyk Khmelnitskogo natsionalnogo universytetu [Bulletin of Khmelnytskyi National University]. Issue 5. pp. 176-182. 


\section{СПИСОК ВИКОРИСТАНОЇ ЛІТЕРАТУРИ}

[1] Абаимов, Р. В. (2011). Повышение эффективности производственной деятельности станций технического обслуживания легковых автомобилей : дис. ... канд. техн. наук : 05.22.10. Орел. 136 с.

[2] Афанасьев, С. В. (2003). Разработка методики управления потенциалом производственной мощности предприятия автосервиса : дис. ... канд. техн. наук : 05.22.10. Москва, 207 с.

[3] Рябченко, С. В. (2009). Экономика и управление предприятиями автосервиса: монография. Санкт-Петербург : Изд-во РГПУ им. А. И. Герцена, 2005. 202 с.

[4] Соколов, А. М. (2009). Развитие системы управления конкурентоспособностью предприятий автосервиса: дис. ... канд. эконом. наук: 08.00.05. Санкт-Петербург, 152 с.

[5] Фирсов, И. В. (2015). Повышение эффективности функционирования станций технического обслуживания на основе совершенствования организационно-производственной структуры: дис. ... канд. техн. наук: 05.22.10. Москва. 153 с.

[6] Чернышов, А. Е. (2005). Комплексная оценка эффективности функционирования автосервисных предприятий: на примере СТО легковых автомобилей : дис. ... канд. техн. Наук : 05.22.10. Москва. 217 с.

[7] Медиковський, М. О., Шуневич О. Б. (2011). Дослідження ефективності методів визначення вагових коефіцієнтів важливості. Вісник Хмельницького національного університету. №5. С. 176-182. 